About authors:

Sterlin Alexander, MD, Fellow of Department of Pediatric Surgery; tel.: +496131170; e-mail: Alexander.Sterlin@unimedizin-mainz.de

Ötzmann von Sochaczewski Christina, MD, PhD, Fellow of Department of Pediatric Surgery;

tel.: +496131170; e-mail: Christina.Oetzmann@unimedizin-mainz.de

Fotache Georgiana, MD, Fellow of Department of Thoracic Surgery; http://linkedin.com/in/georgiana-fotache-b4b16b35

Veronika Engel, MD, PhD, Department of Pediatric Surgery; tel.: +496131170; e-mail: Veronika.Engel@unimedizin-mainz.de

Gödecke Jan, MD, PhD, Department of Pediatric Surgery; tel.: +496131170; e-mail: Jan.Goedecke@unimedizin-mainz.de

Muensterer Oliver, MD, PhD, FAAP, FACS, FEBPS, Univ.-Professor, Department of Pediatric Surgery;

tel.: +49613117111; e-mail: Oliver.Muensterer@unimedizin-mainz.de

(c) Group of authors, 2017

UDC 616.71-018.44-002.2-089.844

DOI - https://doi.org/10.14300/mnnc.2017.12098

ISSN - 2073-8137

\title{
APPLICATION OF POROUS TITANIUM NICKELIDE FOR TREATMENT OF PATIENTS WITH CHRONIC OSTEOMYELITIS
}

Shtofin A. S., Shegolev M. B., Trushin P. V., Golovnev V. A., Golovnev A. V., Shtofin S. G.

Novosibirsk State Medical University, Russian Federation

\section{ПРИМЕНЕНИЕ ПОРИСТОГО НИКЕАИАА ТИТАНА ААЯ АЕЧЕНИЯ БОАЬНЫХ ХРОНИЧЕСКИМ ОСТЕОМИЕАИТОМ}

\author{
А. С. Штофин, М. Б. Щеголев, П. В. Трушин, В. А. Головнев, А. В. Головнев, С. Г. Штофин
}

Новосибирский госуАарственный меАицинский университет, Российская ФеАерация

The research covered patients with chronic osteomyelitis. 55 patients underwent an original operation of single stage sequestrectomy and grafting the residual bone cavity with fine-grain titanium nickelide. There was demonstrated clinico-roentgenologic efficiency of this treatment method in early rehabilitation period and further follow up. Clinical effects were characterized by the absence of relapses of chronic osteomyelitis in $94.6 \%$ of patients during the followup period. The inductive influence of titanium nickelide in the formation of trabecular bone tissue was experimentally based on 20 animals (dogs). Thus, our work confirms that the use sequestrectomy with the following grafting with the granules of titanium nickelide gives more positive results than the traditional method of treatment of the chronic osteomyelitis.

Keywords: chronic osteomyelitis, titanium nickelide, bone grafting, surgical treatment

В исследование включены 83 пациента с хроническим остеомиелитом (ХO), из них 55 больным была проведена оригинальная операция одномоментной секвестрэктомии и пластики остаточной костной полости мелкогранулированным никелидом титана. Продемонстрирована клинико-рентгенологическая эффективность данного метода лечения в раннем реабилитационном и в отдаленном периоде наблюдения. Клинические эффекты характеризовались отсутствием рецидивов XО у 94,6 \% больных в течение всего срока наблюдения. Экспериментально на 20 животных (собаках) было установлено индуцирующее действие никелида титана в процессе формирования зрелой костной ткани. Полученные результаты свидетельствуют о том, что применение метода лечения XO путем секвестрэктомии с последующей пластикой гранулами никелида титана дает большее количество положительных результатов в сравнении с традиционным методом лечения.

Ключевые слова: хронический остеомиелит, никелид титана, пластика, хирургическое лечение

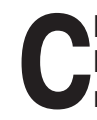
hronic osteomyelitis is pathology of the bone system, accompanied not only by local manifestations, but changes in the whole body. Taking into account that the average age of the patients with chronic osteomyelitis (CO) is $30-40$ years old. In the whole structure of diseases of locomotor organs, CO constitutes 3-6.5\%, occupying the first place among the complications after the operational treatment of closed fractures [1, 2]. In recent years a tendency is noticed towards the increase in the frequency of the disease. Among other purulent-septic diseases, $\mathrm{CO}$ is characterized by long-lasting and progressive development, resistance to treatment, predisposition to relapses [3]. Besides, during the last two decades, the number of patients with postoperational osteomyelitis increased dramatically - up to $34 \%$ among the observed patients [4]. At present, there are no unique criteria in the assessment of efficiency of methods of treating $\mathrm{CO}$, in particular, the elimination of osteomyelitis bone cavities. The opinions of surgeons $[2,5]$ coincide in the question of radical surgical manipulation with osteomyelitis 
focus. It is the fulfillment of sequestrectomy, which must include four stages: a) the removal of necrotic tissues, pus, granulations from a sequestral cavity; b) the removal of a scleroid sequestral capsule to the appearance of sharply marginated areas of bone supplied with blood; c) the opening of the marrowy canal and its lumina above and below the affected area; d) the filling of the residual cavity with biological or other plastic material. The frequency of relapses of the disease after bone grafting with hemo-filling is $3.2-20.6 \%$, after grafting with muscle flap 3.8-28.5 \%, with dermatic-periosteal bone flap $3.9-31.3 \%$, with free bone grafting - 4.9-38.4\% of observations [1, 3, 4]. Various biological, mineral, synthetic or other materials are assessed as debride $[5,6,7]$. All this prompts to search actively to improve the methods of plastic restoration of residual bone cavity in the case of $c 0$. In recent years, a new class of porous super-elastic materials on the basis of titanium nickelide has been developed, which possess unique properties: biochemical compatibility (bio-inertia), physical-chemical properties, close to the parameters of bone tissue, good anti-corrosion properties. Besides, they are not cancerigenic, not toxic, are well sterilized; they possess preset porous structure, penetrance, wetting ability $[9,10,12]$. Living tissues easily germinate into the pores of titanium nickelide, at the same time direct connection is formed between the bone and the implant $[6,8,11]$. It allows them to function in the tissues of the body for a long time, without being rejected, which provides stable regeneration and permits to use implants from porous permeable alloys on the basis of titanium nickelide in the conditions of an infected bone bed.

The goal of research: to study and compare the processes of regeneration of bone tissue in animals while grafting bone cavities with titanium nickelide granules and free plastics in experiment, and also to assess the efficiency of surgical treatment of patients with $\mathrm{CO}$ by the use of grafting post-osteomyelitis cavity with fine-grain porous titanium nickelide.

Material and Methods. To realize the set goal, the results of research were analyzed, which were made on experimental animals (dogs), as well as the results of reconstructive operations with $\mathrm{CO}$ with the use of grafting with fine-grain titanium nickelide.

Experimental procedure. All the research was carried out with the observation of Rules of works with the use of experimental animals. To assess the speed of regeneration of bone tissue of dogs' two methods of bone grafting were experimentally reproduced: a traditional one - with bone crumbs, and the method of filling the bone cavity with fine-grain titanium nickelide, which has been developed lately. In the first group consisting of 20 dogs, granules of porous titanium nickelide were placed in the formed cavity of shin bone epiphysis. In the second (control) group (consisting of 10 dogs) flank-bone crumbs were introduced into the form cavity of the shin bone. The assessment of the experimental data was made in the first and third months after bone grafting.

Clinical part. 83 patients with $\mathrm{CO}$ at the age from 17 to 60 (on the average 37,1 ) were observed. There were 63 men and 20 women. 55 patients (study group) underwent sequestrectomy with the following bone grafting of the residual bone cavity with the granules of titanium nickelide. 28 persons were included into the comparison group, who were treated in the traditional way - sequestrectomy with the filling of sequestral cavity with the hemo-filling. The research included the patients with $\mathrm{CO}$ who had one or more sequestral cavities (Table).
Table

Patients with chronic osteomyelitis

\begin{tabular}{|l|c|c|c|c|}
\hline \multirow{2}{*}{\begin{tabular}{c}
\multirow{2}{*}{$\begin{array}{c}\text { Localization } \\
\text { osteomyelitis } \\
\text { focus }\end{array}$} \\
\cline { 2 - 5 }
\end{tabular}} & \multicolumn{2}{|c|}{$\begin{array}{c}\text { Study group } \\
(\mathrm{n}=55)\end{array}$} & \multicolumn{2}{c|}{$\begin{array}{c}\text { Comparison group } \\
(\mathrm{n}=28)\end{array}$} \\
\hline Thigh bone & 15 & 27.3 & 7 & 25.0 \\
\hline Shin bone & 24 & 43.6 & 12 & 42.9 \\
\hline Humerus & 4 & 7.3 & 2 & 7.1 \\
\hline Heel bone & 4 & 7.3 & 2 & 7.1 \\
\hline Splint-bone & 2 & 3.6 & 2 & 7.1 \\
\hline Huckle bone & 2 & 3.6 & 2 & 7.1 \\
\hline Finger nail-bone & 2 & 3.6 & 0 & 0 \\
\hline \multicolumn{1}{|c|}{ Radial bone } & 2 & 3.6 & 1 & 3.7 \\
\hline
\end{tabular}

The chronicity of the disease was from 3 months to 13 years. The patients with complications of the basic disease, like pseudarthrosis and unconsolidated fracture, were excluded. The formed groups were consistent in gender, age, the duration of the disease, the localization of the pathological process, the number of previously undergone operations, which allowed to validate the accuracy of the obtained results. The clinical form of $\mathrm{CO}$ was established for all the patients. They were chronic post-traumatic osteomyelitis for 62 (75.4\%) patients, chronic hematogenic osteomyelitis for 21 (22.6\%). 62 patients were taken to hospital in the planned manner, 21 - urgently, due to the exacerbation of chronic osteomyelitis, 11 of them had burrowing pus (phlegmon) in soft tissues in the affected area. $63(76 \%)$ patients had a fistula form of $\mathrm{CO}$. The sizes of fistulas were from spot to extensive with osteomyelitis ulceration of the bone on its bottom. The volume of sequestral cavities was on average $18,6 \mathrm{~cm}^{3}$. For an objective assessment of the patients' condition, the complex examination was carried out, which included clinic-laboratory, bacteriological, roentgenological and morphological methods of research. Bacterial cultures were inoculated in $81.1 \%$ of patients: Staphylococcus aureus - in 57 (69.7\%), Streptococcus haemolyticus - in $9(11.6 \%)$, Pseudomonas aeruginosa - in $7(9.3 \%)$, E. coli - in $4(4.7 \%)$ and mixed flora Enterococcus faecalis + Staphylococcus pyogenes - in $4(4.7 \%)$. All 55 patients from the group of clinical study on the basis of surgical clinical picture were treated with single stage plastic restoration of residual bone cavities, which included syringectomy, equestrectomy with grafting a sequestral cavity with the granules of titanium nickelide. When the patients were admitted urgently (with phlegmons), first the opening was made, then the draining of the phlegmon, the sanation during 8-10 days, then, as the second stage, the operation of sequestrectomy with grafting with the granules of titanium nickelide. The operation began with determining the fistulous tract and the syringectomy to the bone, the resection of peri-osteum, the opening of the sequestral box, the removal of sequesters with granulated tissue. Then there was carried out curettage to the appearance of pinpoint bleeding. Then the sequestral cavity was rinsed with the solution of antiseptic and filled with dry sterile granules of titanium nickelide in the amount not less than one third of the volume of the sequestral cavity. The wound was stitched up completely with a rubber tube drainage left for 24 hours. In the post-operational period, antibiotics were prescribed for 5-7 days and physiotherapy. The stitches were taken out on the 7 th-10th day. If necessary, there was carried out plaster immobilization of the limb in the physiological rest position for 3-4 months.

Analysis of the significance of differences in the groups was carried out in variational statistics methods 
throw Microsoft Excel 2010. Data analysis included standard methods of descriptive and analytical statistics. A statistically significant difference in the groups was assessed by t-test, considering significant differences in the groups at $p<0.05$.

Results and Discussion. Results of the experimental research. After 1 postoperative month, impregnations of metal and a slight shadow of tissue, connecting the granules, were radiologically determined in the animals of the first group in the area of the grafting of shin bone epiphysis. In control samples, bone fragments were surrounded with a capsule. Macroscopically it was hard to draw out the granules from the cavity in the first group of dogs by destroying bone structures. In control samples loose connective tissue was located between the fragments of bone tissue. Microscopically, on the prepared slices of shin bone, we discovered that, inside metal pores, bone cells, surrounded with osteomucoid, were located. Nuclei and basophilic cytoplasm were well contoured in them. Thin bone trabeculas developed anastomosis with bone structures formed in the pores of the implant. Besides, bone trabeculas surrounded the granules, connecting them, and anastomosed with bone tissue, surrounding the cavity. After 3 months, in the first group of animals, the granules of titanium nickelide in the zone of operational intervention were surrounded with bone trabeculas forming anastomosis. Macroscopically in the study group the granules in the researched zone of bone tissue were tightly knitted together with the maternal bed by bone trabeculas. Microscopically (slices of shin bone) it was found out that between metal granules and around them trabecular bone tissue of trabecular structure with traces of alteration was located: irregular gluing line and a large number of osteoblasts. Around some trabeculars were seen Gaupschipt's lacunas and osteoclasts. Between trabeculars, bone marrow of myeloid structure was formed. The border between the formed bone structure and maternal bed was absent. There was an organotypic copmplex: bone tissue and the granules of titanium nickelide in the form of single structure. After 3 months in the second group there was discovered of the epiphysis cavity the primitive bone tissue of trabecular structure against the background of osteoclastic resorption of bone fragments, osteoid substance with collagenous fibrils. The complete contact with the maternal bed was not observed. Thus, in the first group of animals, accelerated formation of trabecular bone tissue was observed and, as a result, the filling of a bone defect. Pathogenetic mechanism of apparent osteogenic reaction is the possibility to form bone tissue in the pores of the implant. The corresponding temperature and, probably, the stimulating inductive influence of titanium nickelide contributed into the differentiation of bone marrow stem cells into osteogenic ones and the formation of bone tissue. In the pores of the implant, trabecular bone tissue was formed with the structure analogous to metrical bone. The germination and growth of bone tissue in the porous structure of the implant occurred simultaneously in many pores in the form of separate nuclei (zones), which then proliferated and united into a single tissue system, filling the pores of the implant and connecting their canals [7]. Two months later the regenerate consisted mainly of compact and cancellous bone tissue, in the farthest area from the recipient zone there was distinguished the presence of fibrous bone tissue. The complete formation of bone tissue in the pores inside the implant occurred mainly by the end of the third month after the operation. The structure pattern of tissue in the pores did not practically change with the time.
Results of clinical research. During early post-operational period, it was determined that $4(8.0 \%)$ patients of the study group had post-operative wound pyogenesis and $2(4.0 \%)$ patients revealed the formation of hematoma in the zone of postoperative wound. In the comparison group, these figures were correspondingly $4(14.3 \%)$ and $2(7.1 \%)$; $3(10.7 \%)$ patients had necrosis of wound edges. The post-operational complications were evaluated as a consequence of the presence of a vast defect of tissues before the operation and, as a result of resection of cicatrical wound edges, the lack of tissues for closing the defect. Conservative measures allowed eliminating these complications. All the patients were discharged from hospital in a satisfactory condition. Healing by first intention was observed in 50 patients $(92.0 \%)$ in the study group and in 19 patients $(67.9 \%)$ in the comparison group. The average duration of treatment in hospital for the study group was 11.6 days for planned admittance and 17.7 days for urgent admittance, in the comparison group - 14.8 and 23.6 days, correspondingly. Distant results were followed during the period from 6 months to 5 years. In the study group 52 patients did not have limb pains; there were no relapses of the exacerbation. 3 patients $(5.4 \%)$ had fistulas formed in the operational zone. $\mathrm{n}$ the comparison group $4(14.3 \%)$ patients had periodic pains in the limbs, $5(17.9 \%)$ patients had fistulas, $5(17.9 \%)$ patients had exacerbation of the process. Rh-investigations revealed that the regeneration of bone occurred in both groups, however it considerably predominated in the study group. All the patients in the study group had periosteal bone reaction in the destruction zone, and in the comparison group -24 patients $(85.7 \%)$. A month after the operation, roentgenological research of all the patients of the study group determined the shadow of implant material in the zone of former bone defects, the sharpness of their contours was disappearing. Further the intensity of the shadow from the side of the defect edges increased, and by the time of the $6^{\text {th }}$ month it achieved the criteria of normal bone tissue, which did not alter later. In the comparison group by this time, no patient manifested complete obliteration of bone cavity. Clinical and roentgenological examination determined the relapse of osteomyelitis in 3 (5.4\%) patients in the study group, the result of the realized treatment could be evaluated as good. The function of operated limbs was restored completely, a good cosmetic effect was achieved. In the comparison group the relapse of $\mathrm{CO}$ was determined for $3(10.7 \%)$ patients.

Conclusions. Clinical practice confirms that the use of the treatment method of $\mathrm{CO}$ by sequestrectomy with the following grafting with the granules of titanium nickelide gives more positive results than the traditional method. It is less traumatic, simpler in realization. The use of this technology allows to reduce the number of post-operational complications and negative results in distant periods, shortens the period of hospital treatment, provides the restoration of bone tissue defects in shorter time, decreases the number of relapses of the disease and improves the quality of patients' lives. Thus, clinic-experimental research showed that porous titanium nickelide is a perspective material and can be used for different skeletal pathologies. In the experiment, its use for grafting bone cavity in comparison with bone crumbs demonstrated the formation of bone organo-typical regenerate 3 months earlier. The use of bio-compatible fine-grain titanium nickelide contributes into rapid and efficient completion of inflammation process in bone tissue, simplifies the methodology, reduces the time of operation and the time of rehabilitation period and, as a result, increases the efficiency of treating patients with chronic osteomyelitis. 
References

1. Gostishchev V. K. The basic principles of etiotropic tyherapy of chronic osteomyelitis. Surgery. 1999;(9):3842

2. Nikitin G. D., Rak A. V., Lynnic S. A., Nikolayev V. F., Nikitin D. G. Bone and muscle-bone grafting in treating chronic osteomyelitis and pyogenic pseudarthrosis. SPb., 2002.

3. Kutin A. A., Mosiyenko N. I. Hematogenic osteomyelitis of adults. M., 2000.

4. Noskov V. N., Agarkov V. P., Gostintsev A. A., Dzyuba G. G., Polozhentsev A. A. Practice of treating patients with chronic osteomyelitis of long bones. Pyogenic complications in traumatology and orthopedics: Materials of scientific-practical conference. Novosibirsk, 2005. P. 25-26

5. Chechnyev Y. Y., Yakushenko V. K., Chekanov M. N. Rutkovsky Y. A., Morozov A. Y. [et al.]. The method of filling sequestral cavities with porous fine-grain titanium nickelide in treating chronic osteomyelitis. Implants with shape memory. 2004;(1-2):19-21.

6. Borisov I. V., Amiraslamov Y. A., Blatun L. A. Antibacterial therapy for osteomyelitis (systematized review). Antibiotics and chemotherapy. 2003;(9):37-40.
7. Fomichev N. G. New technologies in spine surgery with the use of implants with shape memory. Tomsk, 2002.

8. Gunter V. E., Dambayev G. T., Sysolyatin P. G. Medical materials and implants with shape memory. Tomsk, 2002.

9. Iryanov Yu. M., Strelkov N. S., Kiryanov N. A., Dyuryagina $\mathrm{O}$. V. Treatment of cavitary bone defects under implantation of the mesh structures made of titanium nickelide. Medical News of North Caucasus 2017;12(2):152-156. doi: 10.14300/mnnc.2017.12043

10. Radkevich A. A., Khodorenko V. N., Gunter V. E. Reparative osteogenesis in bone defects after restoration with porous fine-grain titanium nickelide. Implants with shape memory. 2005; (1-2):30-34.

11. Strelkov N. S., Kiryanov N. A., Shklyaev P. O. Pathomorphology and mineral composition of bone in experimental osteomyelitis. Medical News of North Caucasus. 2015;10(4):415-418. doi: 10.14300/ mnnc.2015.10101

12. Cripps M., Shirtliff M. E., Mader J. T. The treatment of osteomyelitis with hydroxyappatite antibiotic implant in a rabbit model. 8th Intersc. Conf. Antimicrobial Agents Chemother. San Diego, 1998.

About authors:

Stofin Andrey Sergeevich, MD; Associate Professor, Department of general surgery;

tel.: +73832767464; e-mail: department.of.general.surgery@gmail.com

Shegolev Michail Borisovich, MD; Associate Professor, Department of general surgery;

tel.: +73832767464; e-mail: department.of.general.surgery@gmail.com

Trushin Pavel Victorovich, MD, CMSc; Associate Professor, Department of general surgery; tel.: +79039038682; e-mail: tpv1974@rambler.ru Golovnev Vladimir Andreevich, MD; PhD, Professor, Professor of Department of general surgery;

tel.: +73832767464; e-mail: department.of.general.surgery@gmail.com

Golovnev Andrey Vladimirovich, MD, CMSc; Associate Professor, Department of general surgery;

tel. +73832767464; e-mail: department.of.general.surgery@gmail.com

Shtofin Sergey Gridorevich, MD; PhD, Professor, Head of Department of general surgery;

tel. +73832767464; e-mail: department.of.general.surgery@gmail.com

(C) Group of authors, 2017

UDC 636.32:616.11.71-007

DOI - https://doi.org/10.14300/mnnc.2017.12091

ISSN - 2073-8137

\title{
OSTEOPOROTIC SHEEP MANDIBULAR MODEL FOR COMPARATIVE ALVEOLAR BONE HEALING RESEARCH
}

\author{
Sirak S. V. 1, Shchetinin E. V. 1, Bobryshev D. V. ' , Fritsch T. ${ }^{2}$, Giesenhagen B. 3 , \\ Petrosyan G. G. 1, Didenko N. N. 1, Romanenko'R. G. 1, Grimm W.-D. 1,4 \\ 1 Stavropol State Medical University, Russian Federation \\ 2 University of Arad, Romania \\ 3 University of Frankfurt am Main, Germany \\ 4 Witten/Herdecke University, Witten, Germany

\section{ЭКСПЕРИМЕНТААЬНАЯ МОАЕАЬ ОСТЕОПОРОЗА ААЬВЕОАЯРНЫХ КОСТЕЙ У ОВЕЦ АЛЯ СРАВНИТЕАЬНОГО ИССАЕАОВАНИЯ ОСТЕОГЕННЫХ СВОЙСТВ МАТЕРИААОВ}

\author{
С. В. Сирак ${ }^{1}$, Е. В. Щетинин ${ }^{1}$, А. В. Бобрышев ${ }^{1}$, Т. Фрич ${ }^{2}$, Б. Гизенхаген ${ }^{3}$, \\ Г. Г. Петросян 1, Н. Н. АиАенко ', Р. Г. Романенко 1, В.-А. Гримм 1, 4
}

${ }_{1}^{1}$ Ставропольский госуАарственный меАицинский университет, Российская ФеАерация

2 Университет АраА, Румыния

3 Университет франкфурта-на-Майне, Германия

4 Университет Виттен - ХерАекке, Виттен, Германия

In the study was investigated the suitability of the mandibular ridge in osteoporotic sheep for comparative dental implant research, to establish histological protocols for this model, to study the effect of variations in healing of tooth extraction sockets and of an acute $12 \mathrm{~mm}$ bone defects. The hypothesis tested was the post-extraction osteoporotic sheep mandible and the acute $12 \mathrm{~mm}$ bone defect in osteoporotic sheep is a suitable model for comparative dental 